\title{
EFFECT OF DIFFERENT HYGENIC CONDITION DURING MILKING ON BACTERIAL COUNT OF COWS' MILK
}

\author{
M. A. Islam ${ }^{*}$, M. N. Islam ${ }^{1}$, M. A. S. Khan ${ }^{1}$, M. H. Rashid ${ }^{1}$ and S. M. Obaidullah ${ }^{1}$
}

\begin{abstract}
Effect of three hygienic conditions $\left(T_{1}\right.$ - washing and disinfection of udder and teats, milker hands, and a sanitary rinse of milking pails using calcium hypochlorite solution with $200 \mathrm{ppm} \mathrm{Cl} ; \mathrm{T}_{2}$ - washing of udder and teats, milker hands and milking pails with normal water; and $\mathrm{T}_{3}$ - without any kind of preparation of udder and teats, milker hands and milking pails) before milking were studied. Fifteen "Red Chittagong" milking cows were selected and divided into the three treatment groups (5 in each) maintaining under identical management conditions icluding floor hygiene, feeding and post-milking equipment sanitation. Initial bacterial quality as measured by Standard Plate Count (SPC), Coliform Count (CC) and Methylene Blue Reduction Time (MBRT) of milks obtained under $T_{1}, T_{2}$ and $T_{3}$ were significantly $(P<0.01)$ different. On the basis of SPC, CC and MBRT initial bacterial load was highest for $T_{2}$ - milk and lowest for $T_{1}$ - milk Initial SPC of $T_{1}$ was $86 \%$ and $64 \%$ lower than that of $T_{2}$ and $T_{3}$ respectively, whereas CC of $T_{1}$ was $89 \%$ and $69 \%$ lower than that of $T_{2}$ and $T_{3}$, respectively. Standard Plate Count and CC of $T_{3}$ were respectively $43 \%$ and $65 \%$ lower than those of $T_{1}$. The initial MBR time were in the order $T_{1}=T_{3}>T_{2}(P<0.01)$. Results of the present study revealed that milking hygiene has significant effect on initial bacterial count of milk.
\end{abstract}

Key words: Milking hygiene, Red Chittagong cows, Bacterial count

\section{Introduction}

Milk is considered as a universal food. The nutritive pefection of milk has made it not only a unique food for human being but also a medium most favourable for microbial growth. Microorganisms which may gain entry into milk can multiply and bring about spoilage of milk and milk products and render them unsafe due to potential health hazards. It is doubtless that milk is secreted by the cells of the udder in a sterile state but soon become contaminated by bacteria normally present in the udder. During the normal milking operation however, milk is subjected to contamination from the exterior of the udder and adjacent areas, dairy utensils, milk contact surfaces, the hands of milkers or dairy workers, air of the milking parlour, water used and flies. Normally these sources would contributes diversified microbes and might be belonging to pathogens or spoilage microorganisms.

\footnotetext{
* Corresponding author: M. A. Islam, Lecturer, Department of Dairy and Poultry Science Patuakhali Science and Technology University, Patuakhali, Bangladesh

${ }^{1}$ Department of Dairy science, Bangladesh Agricultural University, Mymensingh-2202, Bangladesh
}

(Received: October 29, 2009) 
The hygienic measures taken during and after milking essentially determine what foreign microorganisms enter the milk, including human pathogens. This applies also to their numbers. The count of properly drawn mixed milk from healthy cows is about $100000 \mathrm{ml}^{-1}$, sometimes even less. If however, the hygienic standards during milking are poor, freshly drawn mixed milk can have a much higher count, upto one million $\mathrm{ml}^{-1}$ (Walstra et al., 1999). Since the number and type of organisms in milk usually get increased by contamination, it is necessary right from milking such hygienic conditions should be maintained that minimum number of microorganisms gain entrance into milk. Several investigators suggested that milking hygiene could significantly reduce the microbial count in milk (Petrovic et al., 2006; Koshy and Prasad, 1993 and Sakya and Srivastava, 1982).

Milk production in Bangladesh is characterized by low yield non-descript cows, small producers, production in small lots and under poor hygienic conditions. As a result, milk reaching into market usually with higher microbial load and making it difficult to enforce standards relating to the hygienic quality of milk. Proper milking hygiene to obtain milk of lower initial bacterial load should be concentrated. The present study was taken up with a view to study the effect of milking hygiene on initial bacterial count and the effectiveness of calcium hypochlorite solution (200 ppm Cl) as a sanitary agent for hygienic milking.

\section{Materials and Methods}

This study was conducted at Dairy Farm and Dairy Microbiology Laboratory of the Department of Dairy Science, Bangladesh Agricultural University, Mymensingh, during the period of September to October; 2007.

\section{Preparation of calcium hypochlorite solution}

A stock solution was prepared by making a smooth watery paste of 100 gram of commercial chloride of lime (Bleaching powder) containing 30 percent available chlorine (Cl), and then adding water slowly and stirring thoroughly until the solution amounts to 2 liters. Then it was allowed to settle and strained into a tightly closed glass bottle. The stock solution was kept in a cold dark room. For the final use $250 \mathrm{ml}$ of this stock solution was added to every 20 liters of water and mixed thoroughly. So, prepared final solution contains approximately 200 ppm (187 parts of available chlorine to 1,000,000 parts of water) chlorine, which is the strength recommended for farm use. This final solution was immediately used. Used solution was thrown away and new one mixed daily. The stock solution was used for maximum 7-8 days and new stock solution was prepared once a week.

\section{Experimental procedure}

Fifteen milking cows were selected from the elite herd of Red Chittangong Cattle Project maintained at BAU Dairy Farm. Cows were of similar yield characteristics, and randomly divided into three treatment groups containing five (5) cows in each. All the milking cows were maintained under identical managemental conditions including floor hygiene, 
feeding and post milking equipment sanitation. Udder and teats of five cows were washed with 200 ppm chlorine solution (previously made), milking pails and milkers' hands were also sanitized with the same solution before milking. Three hygenic conditions represents are $T_{1}, T_{2}$ and $T_{3}$ respectively. In $T_{1}$ group, calcium hypochlorite solution (200 ppm Cl) was used as a sanitary agent for pre-milking washing and disinfection of udder and teats, hands of milker, and milking pails; in $T_{2}$ group, milking was done in wet condition after washing udder and teats, hands of milker, and milking pails with normal water; and in $T_{3}$ group, udder and teats, hands of milker and milking pails were not prepared by any means.

Milking was done by hand and in open pails. Mixed milk samples of $250 \mathrm{ml}$ from individual treatment groups were taken into three sterile bottles and kept in ice box. Milk samples were brought to laboratory for analysis immediately after milking. Milk samples were collected at an interval of 3-4 days for analysis during the study period. The milk samples were analyzed for initial microbial quality with the help of Standard Plate Count (SPC), Coliform Count (CC), Methylene Blue Reduction Time (MBRT) test. All the parameters were studied as per the procedure described in the Standard Methods for the Examination of Dairy Products (APHA, 1998).

The statistical analyses were done by plotting experimental data in Completely Randomized Design (CRD). Statistical package MSTAT-C was used for analytical purpose. In case of significant difference LSD test was carried out to find out the significant difference among different treatment means.

\section{Results and Discussion}

In the present study, milk samples were collected from cows maintained under three different hygienic conditions $\left(T_{1}, T_{2} \& T_{3}\right)$ before milking. The initial (immediately after milking) microbiological quality was determined by performing Standard Plate Count (SPC), Coliform Count (CC), Methylene Blue Reduction Time (MBRT) test. The results of trials conducted along with necessary discussions are presented below:

\section{Standard plate count}

Results of Standard Plate Count (SPC) as obtained from milks of different hygienic groups are presented in Table 1. The mean values of initial SPC were $57 \pm 13,411 \pm 75$ and $161 \pm 37$ thousand cfu/ml for $T_{1}, T_{2}$ and $T_{3}$ milk, respectively. The mean SPC values were significantly different $(P<0.01)$. The mean initial SPC was in the order of $T_{1}<T_{3}<T_{2}$ Thus the lowest and highest initial bacterial load was found in the hygiene group $T$, and $T_{2}$ respectively.

Results obtained from each trial represented that wet milking $\left(T_{2}\right)$ is a major cause of high initial bacterial count. This may be due to dripping of surplus water (that contains enormous number of bacteria) from the udder and adjacent areas into milk and may also be due to the fact that higher degrees of wetness of udder and milker hands help leaching of dirt and bacteria from teats, udder and hands into milk. Thus, making the 
milk unclean with increased bacterial count. Similar comments have been reported from Galton et al. (1984) and Hogan et al. (1979) in their studies on milking hygiene. Both of them reported that higher degree of wetness of udder surface and teats is associated with increased number of bacteria in milk. In contrast to $T_{2}$, the initial bacterial load of $T_{3}$ was reduced by as much as $61 \%$ and representing that milking in dry condition significantly reduces bacterial count. It is because no surplus water remains in the surface of the udder to drip into the milk and due to less chance of leaching dirt and bacteria from udder, teats and hands into milk. Thus merely cleaning and washing is not sufficient, rather drying of udder and hands is important to obtain clean milk.

Table 1. Standard plate counts $(\times 103 \mathrm{cfu} / \mathrm{ml})$ under different hygienic conditions

\begin{tabular}{|c|c|c|c|c|c|c|c|c|c|c|c|c|}
\hline \multirow{2}{*}{$\begin{array}{l}\text { Hygiene } \\
\text { groups }\end{array}$} & \multicolumn{9}{|c|}{ SPC at different observation days } & \multirow{2}{*}{ Mean \pm SD } & \multirow{2}{*}{ CV } & \multirow{2}{*}{ Level of sig } \\
\hline & 1 & 2 & 3 & 4 & 5 & 6 & 7 & 8 & 9 & & & \\
\hline $\mathrm{T}_{1}$ & 36 & 67 & 53 & 49 & 57 & 8- & 55 & 47 & 70 & $57 \pm 13^{c}$ & & \\
\hline $\mathrm{T}_{2}$ & 510 & 340 & 285 & 390 & 430 & 470 & 360 & 500 & 410 & $411 \pm 75^{\mathrm{a}}$ & 23 & ** \\
\hline $\mathrm{T}_{3}$ & 115 & 150 & 143 & 165 & 229 & 160 & 157 & 209 & 121 & $161 \pm 37^{b}$ & & \\
\hline
\end{tabular}

** $(P<0.01)$

${ }^{a b c}$ means values in the same column with different superscripts differ significantly

In $T_{1}$ group initial SPC was far too lower than $T_{2}$ and $T_{3}$. This may be due to the effect of disinfection of udder and milkers hands and sanitary rinse of milking pails prior to milking. Initial SPC of $\mathrm{T}_{1}$ was as much as $86 \%$ and $65 \%(64.59)$ less than the counts obtained respectively from $\mathrm{T}_{2}$ and $\mathrm{T}_{3}$ group. Schoken-Iturrino et al. (1982) studied the effect of several sanitary measures during milking on the microbial count of milk. Samples were taken during milking from 16 friesian cows milked by hand (i) Without any preparation or with (ii) udder preparation with sodium hypochlorite solution with active $\mathrm{Cl}$ at 5 ppm (iii) preparation of udder and milkers' hand or (iv) preparation of udders, hands and teat cups. Bacterial count in milk decreased in the order (i) $>$ (ii) $=$ (iii) $>$ (iv) $(P>0.05)$. Differences in the mean bacterial count among milking were significant at $1 \%$ level. Sakya and Srivastava (1982) reported a $79.7 \%$ and $83.6 \%$ reduction $(P<0.01)$ in mean bacterial count by washing and disinfection $(200 \mathrm{ppm} \mathrm{Cl}$ ) of milker hands and cows' udder respectively. Petrova and Petroava (1985) showed that bacterial counts were halved by washing udder with a disinfectant as opposed to using only a dry cloth for cleaning. Results of the present study are in agreement with the findings of previous investigators. The drastic reduction in initial SPC in $T_{1}$, compared to $T_{2}$ and $T_{3}$ may be attributed to combined cleaning and sanitizing effect of chlorine solution. Results of individual observation days as presented in the Table 1 showed considerable variation within each treatment group.

\section{Coliform count}

Results of coliform count (CC) for $\mathrm{T}_{1}, \mathrm{~T}_{2}$ and $\mathrm{T}_{3}$ are presented in Table 2. The mean values of $\mathrm{CC}$ were $38 \pm 20,359+90$ and $123+20 \mathrm{cfu} / \mathrm{ml}$ for $\mathrm{T}_{1}, \mathrm{~T}_{2}$ and $\mathrm{T}_{3}$, respectively. The mean values of $\mathrm{CC}$ showed significant difference $(\mathrm{P}<0.01)$. The mean $\mathrm{CC}$ was in the order of $\mathrm{T}_{2}>\mathrm{T}_{3}>\mathrm{T}_{1}$. Highest mean coliform count $(359 / \mathrm{ml})$ was found in $\mathrm{T}_{2}$ and the mean values of $\mathrm{T}_{3}(123 / \mathrm{ml})$ and $\mathrm{T}_{1}(38 / \mathrm{ml})$ were reduced respectively by 
$65 \%$ and $89 \%$ compared to $\mathrm{T}_{2}$. The mean CC of $\mathrm{T}_{1}$ was reduced by $69 \%$ compared to $\mathrm{T}_{3}$. Results of individual observation days as presented in the Table 2 showed considerable variation within each treatment group and such variation is not unusual.

Table 2. Coliform Counts (cfu/ml) under different hygienic conditions

\begin{tabular}{|c|c|c|c|c|c|c|c|c|c|c|c|c|}
\hline \multirow{2}{*}{$\begin{array}{l}\text { Hygiene } \\
\text { groups }\end{array}$} & \multicolumn{9}{|c|}{ CC at different observation days } & \multirow{2}{*}{ Mean \pm SD } & \multirow{2}{*}{ CV } & \multirow{2}{*}{ Level of sig } \\
\hline & 1 & 2 & 3 & 4 & 5 & 6 & 7 & 8 & 9 & & & \\
\hline $\mathrm{T}_{1}$ & 0 & 45 & 41 & 35 & 38 & 69 & 53 & 0 & 62 & $38 \pm 20^{c}$ & & \\
\hline $\mathrm{T}_{2}$ & 470 & 300 & 184 & 410 & 330 & 360 & 390 & 480 & 310 & $359 \pm 90^{a}$ & 32 & ** \\
\hline $\mathrm{T}_{3}$ & 96 & 107 & 105 & 124 & 154 & 142 & 135 & 149 & 98 & $123 \pm 20^{b}$ & & \\
\hline
\end{tabular}

** $(\mathrm{P}<0.01)$

${ }^{a b c}$ means values in the same column with different superscripts differ significantly

It is worth mentioning here that the initial coliform count was negative for 2 observations under $\mathrm{T}_{1}$, indicating that proper cleaning and disinfection of cows' udder, milkers' hands and milking equipment results great reduction in coliform count. The initial coliform count of each trial under $T_{1}$ was below the coliform standard $(100 / \mathrm{ml})$ for raw milk. Percentage reduction of CC was higher than the reduction of SPC. It may be due to the fact that unsanitary conditions help increased contamination of milk by coliform, and contamination originating from udder, hands, equipment and also water used associated with coliform groups. Henderson (1971) stated that organisms associated with dirt such as manure, bedding, and soil are often of gas forming Escherichia-acrobacter group and may fall from the belly, flanks, tail, and udder into the milk pail and thus carry a considerable number of bacteria into the milk. It may also be attributed to faster germicidal action of hypochlorite and its more effectiveness against the coliforms. The reduction of mean $\mathrm{CC}$ under $\mathrm{T}_{3}$ compared to $\mathrm{T}_{2}$ essentially determine the effectiveness of dryness of udder surface during milking and also indicate that udder surface is an important sources of coliform bacteria.

From the results it was found that disinfection of udder and teats, milkers' hands, and sanitary rinse of pails all had significant effect to the reduction of coliform count in freshly drawn milk samples. Hogan et al. (1984) attributed higher coliform count to the degree of wetness of udder; Petrova and Petrova (1985) showed that udder disinfection (Cl 5 ppm) can half the coliform count in milk; but Sakya and Srivastava (1982) showed non-significant effect of udder disinfection $(200 \mathrm{ppm} \mathrm{Cl})$ on coliform count; and Kantona and Szita (1982) attributed increased coliform count to the improper equipment sanitation. The present experiment design does not support to make such specific distinction but results are in overall agreement with the previous findings and suggest that proper hygienic measure during milking significantly reduce the incidence of coli counts in milk.

\section{Methylene blue reduction time test}

Results of Methylene Blue Reduction Time (MBRT) test are presented in Table 3. The mean MBRT of $T_{1}, T_{2}$ and $T_{3}$ groups were $693 \pm 23,513 \pm 85$ and $650 \pm 45$ minutes, 
Bang. J. Anim. Sci. 2009, 38(1\&2)

respectively. The mean values of MBRT were highest in $T_{1}$. There was non significant difference between $T_{1}$ and $T_{3}$ but difference between $T_{1}$ and $T_{2}$, and $T_{2}$ and $T_{3}$ were significant $(P<0.01)$.

Table 3. Methylene blue reduction time (minute) under different hygienic conditions

\begin{tabular}{|c|c|c|c|c|c|c|c|c|c|c|c|c|}
\hline \multirow{2}{*}{$\begin{array}{l}\text { Hygiene } \\
\text { groups }\end{array}$} & \multicolumn{9}{|c|}{ MBRT at different observation days } & \multirow{2}{*}{ Mean \pm SD } & \multirow{2}{*}{ CV } & \multirow{2}{*}{ Level of sig } \\
\hline & 1 & 2 & 3 & 4 & 5 & 6 & 7 & 8 & 9 & & & \\
\hline $\mathrm{T}_{1}$ & 720 & 690 & 690 & 720 & 720 & 660 & 690 & 660 & 690 & $693 \pm 23^{a}$ & & \\
\hline $\mathrm{T}_{2}$ & 360 & 510 & 570 & 600 & 540 & 510 & 600 & 390 & 540 & $513 \pm 85^{b}$ & 9 & ** \\
\hline$T_{3}$ & 720 & 660 & 660 & 630 & 600 & 630 & 630 & 600 & 720 & $650 \pm 45^{\mathrm{a}}$ & & \\
\hline
\end{tabular}

** $(\mathrm{P}<0.01)$

${ }^{a b c}$ means values in the same column with different superscripts differ significantly

Day to day observation showed less variation (CV-9.27\%) in MBRT compared to SPC and $\mathrm{CC}$. Thus the results of MBRT fail to determine the initial microbial quality of milk compared to SPC in the case where the contamination level is low. MBRT places all the milk samples in the Good grade where SPC places $T_{1}$ and $T_{3}$ in the Very good grade and $T_{2}$ in the good grade, according to Prasad (1997) and IS (1962) recommendations, respectively. Similar finding have been reported from Sinha el al. (1968), Lakhani and Singh (1998) and Marutirum and Singh (1967). Grag and Mandokhot (1997) observed that MBRT places milk samples in a higher grade than it is placed by $5^{\circ} \mathrm{C}$.

\section{Conclusion}

The study revealed that milking clean cows in dry condition gives better initial bacterial quality of milk compared to washing of udder, milker hands and milking pails with normal water before milking. Washing and disinfection of udder and milkers' hands, and sanitary rinse of milking pails just before milking significantly improved initial bacterial quality of milk. The calcium hypochlorite solution $(200 \mathrm{ppm} \mathrm{Cl})$ can be used as an effective sanitizer in milking hygiene operations to improve initial bacterial quality of milk.

\section{Acknowledgements}

The authors are grateful to Dr. A. K. F. H. Bhuiyan, Professor, Department of Animal Breeding and Genetics, Bangladesh Agricultrual University and Principal investigator "Red Chittagong Cattle Project" for his co-operation during the experimental period. The logistic support received from the Department of Dairy Science, Bangladesh Agricultural University is gratefully acknowledged. 


\section{Literature Cited}

APHA (American Public Health Association). 1998. Standard methods for the Examination of Dairy Products. $20^{\text {th }}$ edn. APHA. Inc. New York.

Galton, D. M., Peterson, L. G., Meriii, W. H., Tsarder, D. K. and Shuster, D. E. 1984. Effect of premilking udder preparation on bacterial population, sediment and iodine residue in milk. Dairy Sci. Abs. 47: 173.

Grag, S. R. and Mandokhot, U. V. 1997. Reliability of rapid and routine quality control tests for grading raw milk under Indian conditions. J. Food Sci. and Tech. Mysore 34(4): 357-359.

Henderson, J. L. 1971. The fluid milk industry ( $3^{\text {rd }}$ edn.). The Avi Publishing Company, Inc. Westport, Connecticut. pp. 64.

Hogan, W. A., Galton, Jr. O. M., Adkinson, R. E. and Pankey, J. W. 1979. Effect of Pre-milking Udder Preperation on Milk Quality. Dairy Sci. Abs. 41: 869.

IS 1479 (Part 11I). 1962. Bacteriological analysis of milk. Indian Standards Institution, Manak Bhavan, New Delhi.

Kantona, F. and Szita, G. 1982. Studies on Indicator Flora for Bacterial Contamination of Raw Milk. Dairy Sci. Abs. 45:396.

Koshy, J. K. and Prashad, J. 1993. Studies on post milking treatments of mammary quarters in production of low bacterial count milk. Ind. Vet. J. 70(8): 773-774.

Lakhani, G. P. and Singh, V. P. 1998. Keeping quality of raw milk by machine milking versus hand milking in buffaloes. J. Dairying Foods \& Home Sci. 17(I): 75-77.

Matutiram, B. and Singh, S. P. 1968. Studies in bacteriological quality of milk. Ind. J. Dairy Sci. 21(2): 103-111.

Petrova, N. and Petrova, M. 1985. Effect of udder cleaning prior to milking Oil microbiological quality of milk. Zhivotnov. 'dn' Nauki 22: 40-45.

Petrovic, iV1., Pavicic, Z., Tomaskovic, A. and Cergoij, M. 2006. Effect of milking hygiene to the number of bacteria in milk. Stocarstvo 60(6): 403-411

Prasad, J. 1997. Animal husbandry and dairy science. Kalyani Publishers, Ludhiana- 141008. pp. 323.

Sakya, S. K. and Srivastava, D. N. 1982. Effect of hygienic practices at the farm on the bacteriological quality of buffalo milk. Haryana Agril. J. Res. 12(4): 535-540.

Schocken-Ituriøino, R. P., Nader Filho, A., Avila, F. A., Motanholi, R. A. 1982. Effect of several sanitary measures during milking on the total microbial counts of milk. Dairy Sci. Abs. 95: 8.

Sinha, R. N., Singh, 1. P. and Nambudripad, V. K. N. 1968. Studies on the keeping quality of pasteurized milk. Ind. J. Dairy Sci. 21: 1-5.

Walstra, P., Geurts, T. J., Noomen, A., Jellema, A. and Van Boekel. M. A. J. S. 1999. DAIRY TECHNOLOGY-Principles of Milk Properties and Processes. Marcel Dekker, Inc. New York. 